\title{
MODEL PEMBELAJARAN CIRC DALAM MENINGKATKAN KETERAMPILAN MENULIS PUISI MELALUI SISWA KELAS V SD
}

\author{
Ella Setiyaningsih, Sutansi, Suhel Madyono \\ Universitas Negeri Malang \\ e-mail: sutansi.fip@um.ac.id
}

\begin{abstract}
Abstrak: Penelitian bertujuan untuk mendeskripsikan keterampilan menulis puisi yang telah diaplikasikan dan dikembangkan melalui Model Pembelajaran Kooperatif Terpadu, Membaca dan Komposisi (CIRC) pada siswa kelas lima SD Negeri 02 Sidodadi Kabupaten Blitar. Subyek siswa kelas V SDN Sidodadi 02 sebanyak 28 siswa. Jenis penelitian ini menggunakan penelitian tindakan kelas (PTK) dengan 4 tahapan yaitu 1) perencanaan, 2) pelaksanaan, 3) pengamatan dan 4) refleksi. Hasil penelitian dapat disimpulkan siklus I kegiatan guru 87,5\% meningkat menjadi 100\% siklus II. Siklus kegiatan siswa 73,1\% meningkat menjadi 94,6\% siklus II. Persentase siklus kelengkapan rata-rata klasik I 64,4\% (kurang) meningkat menjadi 92,8\% (sangat baik) siklus II.
\end{abstract}

Kata kunci: keterampilan menulis puisi, puisi, model pembelajaran sirkus

Bahasa Indonesia merupakan salah satu mata pelajaran yang diberikan di Sekolah Dasar. Berdasarkan dokumen BSNP (2006:318) "ruang lingkup mata pelajaran bahasa Indonesia mencakup komponen kemampuan berbahasa dan kemampuan bersastra yang meliputi aspek-aspek mendengarkan, berbicara, membaca dan menulis". Salah satu kemampuan berbahasa itu adalah keterampilan menulis. Iskandarwassid (2015: 291) keterampilan menulis ialah keterampilan tertinggi tingkat kesulitannya bagi pembelajar dibandingkan dengan ketiga keterampilan lainnya. Mudiono (2010:80) "keterampilan menulis merupakan keterampilan proses yang ada dasarnya bukan hanya menuangkan ide ataupun gagasannya kedalam bentuk tulisan, tetapi lebih kepada proses kreatif agar siswa bisa menuangkan ide, ataupun gagasannnya kedalam sebuah wacana". Berdasarkan kedua pendapat tersebut disimpulkan bahwa keterampilan menulis merupakan keterampilan yang berkaitan dengan kegiatan menuangkan gagasan maupun ide secara tertulis untuk mengembangkan daya kreativitas seseorang, sehingga isi tulisan tersebut dapat dipahami pembaca.

Hasil observasi yang dilakukan di SDN Sidodadi 02 Kabupaten Blitar yang dilaksanakan pada 9 Januari 2017 pada pembelajaran menulis puisi yaitu proses pembelajaran yang dilakukan guru belum memberikan apersepsi siswa dan guru masih menggunakan metode ceramah sehingga siswa cenderung pasif. Pembelajarannya dilakukan secara klasikal tidak berkelompok sehingga kondisi kelas menjadi ramai. Guru tidak menggunakan media pembelajaran. Selain itu guru tidak menjelaskan materi tentang unsur-unsur fisik pembangun puisi, dan cara menulis puisi secara detail. Sehingga berakibat pada hasil belajar/ keterampilan menulis puisi siswa yang masih rendah. Hal ini terlihat dari hasil wawancara yang dilakukan peneliti pada 12 Januari 2017 kepada guru kelas yaitu: sebelum guru menga- 
jar mempersiapkan RPP beserta instrumennya dan materi dibuku paket. Dalam pembelajaran masih menggunakan metode ceramah yang dipadukan metode tanya jawab dan penugasan. Nilai Kriteria Ketuntasan Minimal (KKM) yang ditentukan sekolah yaitu 80 . Maka nilai hasil menulis puisi siswa masih rendah. Hal ini di lihat dari nilai rata-rata siswa kelas $\mathrm{V}$ yaitu 77,3 dengan 28 siswa atau $100 \%$, hanya 11 siswa atau 39\% yang tuntas dan 17 siswa atau $61 \%$ siswa belum tuntas. Serta kesulitan yang dialami siswa ialah: (1) siswa kesulitan menentukan pilihan kata dalam menulis puisi, (2) siswa kesulitan dalam menyusun kata-kata menjadi kalimat dalam bait puisi, (3) siswa kesulitan menggunakan unsur-unsur fisik pembangun puisi meliputi, citraan/pengimajinasian dan majas/bahasa figuratif dalam menulis puisi.

Berdasarkan permasalahan yang diperoleh di SDN Sidodadi 02, maka peneliti melakukan penelitian tindakan kelas dengan menerapkan model pembelajaran Cooperative Integrated Reading, and Composition (CIRC). Slavin (2010: 16) CIRC ialah program komprehensif untuk mengajarkan membaca dan menulis di kelas SD pada tingkat yang lebih tinggi dan menengah. Dengan menggunakan model ini dapat meningkatkan keterampilan menulis puisi pada siswa, karena CIRC memfokuskan pada kegiatan menulis dan membaca. Model pembelajaran CIRC memiliki kelebihan. Menurut Shoimin kelebihannya, (2016: 54) meliputi: CIRC sangat tepat untuk meningkatkan keterampilan siswa dalam menyelesaikan soal pemecahan masalah, (2) dominasi guru dalam pembelajaran berkurang, (3) siswa termotivasi pada hasil secara teliti karena bekerja dalam kelompok, dan (4) meningkatkan nilai hasil belajar keterampilan menulis puisi siswa. Fase model pembelajaran CIRC menurut Shoimin (2016: 53) yaitu yaitu: (a) fase pertama orientasi, (b) fase kedua organisasi, (c) fase ketiga pengenalan konsep, (d) fase keempat publikasi, dan (e) fase kelima penguatan dan refleksi.
Berdasarkan permasalahan yang diperoleh di SDN Sidodadi 02 maka dirumuskan masalah yaitu: (1) Bagaimana penerapan model pembelajaran CIRC untuk meningkatkan keterampilan menulis puisi pada siswa kelas V SDN Sidodadi 02 Kabupaten Blitar? dan (2) Apakah setelah menerapkan model pembelajaran CIRC dapat meningkatkan keterampilan menulis puisi pada siswa kelas $\mathrm{V}$ di SDN Sidodadi 02 Kabupaten Blitar?

Pembelajaran menulis sangat penting dipelajari karena bertujuan untuk melatih keterampilan menulis bagi siswa. Menurut Byrne (dalam Saddhono dan Slamet 2014: 163) keterampilan menulis adalah kemampuan menuangkan buah pikiran ke dalam bahasa tulis melalui kalimat-kalimat yang dirangkai secara utuh, lengkap, dan jelas sehingga buah pikiran tersebut dapat dikomunikasikan kepada pembaca dengan berhasil. Pembelajaran menulis puisi dipelajari di kelas tinggi. Menurut Wardoyo (2013:61) "menulis puisi yakni menuangkan pikiran atau perasaan melalui tulisan yang mengandung daya sugestif bagi pembaca". Menulis puisi termasuk salah satu keterampilan. Jadi keterampilan menulis puisi harus selalu dilatih, karena tanpa dibimbing dan latihan menulis puisi tujuan pembelajaran tidak tercapai.

Aspek yang dinilai yaitu unsur-unsur fisik pembangun puisi menurut Supriyadi(2006:67) yang terdiri dari: (1) citraan/pengimajinasian penglihatan, pendengaran dan perabaan. (2) majas/gaya bahasa personikasi, simile dan repitisi. (3) Pilihan kata (diksi) yang tepat dengan menggunakan kiasan. Hal ini diperkuat dengan kriteria penilaian menurut Nurgiyantoro (dalam Iskandarwassid, 2015: 250) bahwa penilaian yang dilakukan terhadap karangan puisi siswa bersifat holistis dengan 2 kriteria yaitu komposisi (citraan) dan gaya dan bentuk bahasa (penggunaan majas dan pilihan kata/diksi). Tulisan mendeskripsikan model pembelajaran CIRC dalam meningkatkan keterampilan menuls puisi pada siswa SD kelas V. 


\section{METODE}

Jenis penelitian yang digunakan pada penelitian ini yaitu Penelitian Tindakan Kelas (PTK). Penelitian ini dilaksanakan sebanyak 2 siklus. Setiap siklus terdapat 2 kali pertemuan. Model penelitian tindakan menurut Arikunto dkk (2010:16) "terdapat empat tahapan yaitu (1) perencanaan, (2) pelaksanaan, (3) pengamatan, dan (4) refleksi". Teknik pengumpulan data yang digunakan yaitu observasi, tes, wawancara, catatan lapangan, dan dokumentasi. Data yang dikumpulkan dalam penelitian ini adalah data proses dan data hasil. Data proses diperoleh dari hasil pengamatan aktivitas siswa dan guru dalam menerapkan model CIRC saat menulis puisi dengan sumber data guru (peneliti) dan siswa kelas V. Data hasil diperoleh dari hasil menulis puisi siswa. Sumber data yaitu siswa kelas V SDN Sidodadi 02 Kabupaten Blitar. Aspek yang dinilai dalam keterampilan menulis puisi ini yaitu mengandung unsur-unsur fisik pembangun puisi terdiri dari citraan/pengimajinasian, majas/gaya bahasa dan pilihan kata (diksi) yang tepat.

Kehadiran peneliti di kelas untuk mengidentifikasi masalah yang terjadi pada keterampilan menulis puisi. Peran peneliti sebagai perencana kegiatan, pelaksana pembelajaran, pengumpul data, penganalisis dan pelapor hasil penelitian. Penelitian dilakukan di kelas V SDN Sidodadi 02 yang beralamat di Jalan Raya Sidodadi RT 01 / RW 01, Desa Sidodadi, Kecamatan Garum, Kabupaten Blitar pada semester genap tahun pelajaran 2016/2017. Sarana dan prasarana di SDN Sidodadi 02 sudah lengkap yaitu 13 ruang yang terdiri dari 6 ruang kelas, 1 ruang kepala sekolah, 1 ruang guru, 1 ruang sanggar pramuka, 1 ruang laboratorium, 1 ruang mushola, 1 ruang UKS, dan 1 ruang perpustakaan. Jumlah guru dan staf TU di SDN Sidodadi 02 yaitu 11 orang.

Subjek penelitian ini adalah siswa kelas V SDN Sidodadi 02 Kecamatan Garum, Kabupaten Blitar dengan jumlah 28 siswa, yang terdiri dari 17 siswa laki-laki siswa dan 11 siswa perempuan. Penelitian dilakukan pada semester genap tahun pelajaran 2016/2017.
Alasan siswa kelas $\mathrm{V}$ dijadikan subjek penelitian yaitu siswa kelas V berusia 11-12 tahun. Menurut Hitipiew (2009:109) "siswa usia 6 sampai 11/12 tahun merupakan tahap Piaget ketiga, yaitu tahap operasional konkrit. Tahap ketiga, operasional konkrit, anak mulai mampu berpikir logik (operasional) namun masih sebatas konkrit". Sehingga siswa kelas $\mathrm{V}$ dapat mengungkapkan konsep yang ditemukan pada gambar dan merangkai kata menjadi kalimat dalam bentuk puisi.

Rancangan penelitian meliputi tahap perencanaan, pelaksanaan, pengamatan, dan refleksi. Tahap perencanaan yaitu menentukan KD, membuat RPP dengan menerapakan model pembelajaran CIRC, menyiapkan media pembelajaran, LKK, tes menulis puisi dan lembar aktivitas guru dan siswa. Tahap pelaksanaan, peneliti melaksanakan pembelajaran sesuai fase-fase di RPP dengan model pembelajaran CIRC. Tahap pengamatan, guru kelas V mengamati proses pembelajaran yang dilakukan peneliti dengan menerapkan model pembelajaran CIRC. Objek observasi yaitu aktivitas guru dan siswa selama pelaksanaan pembelajaran dengan model pembelajaran CIRC. Pengamatan dilakukan berdasarkan lembar observasi aktivitas guru dan siswa. Pada tahap refleksi peneliti melakukan kegiatan mengkaji dan menganalisis secara menyeluruh tindakan yang telah dilakukan, berdasarkan data yang telah terkumpul pada pelaksanaan penelitian siklus I dan siklus II. Berdasarkan data yang diperoleh, kemudian dilakukan evaluasi untuk menyempurnakan tindakan siklus II. Sehingga permasalahan yang ditemukan dapat dipecahkan secara optimal. Keempat tahap tersebut berlaku untuk setiap siklus.

Analisis data dilakukan setelah pelaksanan tindakan untuk setiap siklus. Pada penelitian ini menggunakan analisis data kualitatif, yaitu menguraikan data yang diperoleh disetiap siklus untuk mengetahui keefektifan penerapan model pembelajaran CIRC sebagai upaya peningkatan keterampilan menulis puisi. Menurut Miles and Huberman (dalam Sugiyono 2013:337) mengemukakan bahwa 
"langkah-langkah dalam analisa data yaitu data reduction, data display, dan conclusion drawing/verification". Pada penelitian ini, data yang terkumpul berupa hasil menulis puisi, observasi dan catatan lapangan.

\section{HASIL}

Berdasarkan aktivitas guru dan siswa, dalam menerapkan model pembelajaran CIRC yang telah dilaksanakan dengan sangat baik dan sesuai di RPP. Aktivitas guru pada siklus I pertemuan 1 belum optimal, karena ada 3 deskriptor dari fase-fase model pembelajaran CIRC belum dilakukan yaitu (1) guru belum menyampaikan aspek yang dinilai, (2) guru belum memberi penguatan materi kepada siswa, dan(3) guru belummemberi kesempatan pada siswa untuk menanyakan materi yang belum dipahami. Hal ini disebabkan oleh guru belum menguasai model pembelajaran CIRC dengan baik. Sehingga persentasenya sebesar $85 \%$ dengan kategori baik. Aktivitas guru pada siklus I pertemuan 2 masih ada 1 deskriptor fase model pembelajaran CIRC yang belum dilaksanakan yaitu guru belum memberi masukan pada setiap perwakilan kelompok yang menampilkan puisinya. Sehingga persentase aktivitas guru pertemuan 2 sebesar 95\% dengan kategori sangat baik. Aktivitas guru pada siklus II pertemuan 1 dan 2 telah dilaksanakan dengan sangat baik, karena persentase aktivitas guru pada siklus II pertemuan 1 sebesar 100\% dengan kategori sangat baik dan pada pertemuan 2 juga mencapai $100 \%$ dengan kategori sangat baik.

Aktivitas siswa dalam menerapkan model pembelajaran CIRC dari siklus I ke siklus 2 juga mengalami peningkatan. Persentase aktivitas siswa pada siklus I pertemuan 1 sebesar $67,9 \%$ dengan kategori kurang. Pertemuan 2 persentase aktivitas siswa meningkat sebesar $78,5 \%$ termasuk dalam kategori cukup. Hal ini dikarenakan (1) siswa belum paham tentang unsur-unsur fisik pembangun puisi, sehingga puisi yang ditulis siswa masih pendek, menggunakan kalimat sehari-hari dan seba- gian besar masih belum mengandung 3 unsur pembangun fisik puisi, (2) siswa kurang percaya diri, (3) siswa membutuhkan waktu yang lama saat menulis puisi. Sehingga ratarata persentase aktivitas siswa pertemuan 1 dan 2 sebesar 73,1\% dengan kategori cukup. Persentase Aktivitas siswa pada siklus II pertemuan 1 sebesar 89,3 dengan kategori baik. Pada pertemuan 2 persentase aktivitas siswa meningkat menjadi $100 \%$ dengan kategori sangat baik. Hal ini dikarenakan siswa terlibat dalam kegiatan pembelajaran dengan kelompok-kelompok kecil. Siswa menjadi lebih aktif, percaya diri dan bertanggung jawab dengan menyelesaikan tugas sebelum waktu yang ditentukan dengan hasil yang baik setelah menerapkan model pembelajaran CIRC. Sehingga rata-rata persentase aktivitas siswa pada siklus II yaitu 94,6\% dengan kategori sangat baik.

Aktivitas guru dan aktivitas guru berdampak pada nilai hasil keterampilan menulis/hasil belajar siswa. Pada siklus I pertemuan 1 siswa yang tuntas adalah 17 dengan persentase ketuntasan belajar klasikal sebesar $61 \%$ termasuk dalam kategori kurang dengan nilai rata-rata kelas sebesar 79,3. Pada pertemuan 2 siswa yang tuntas adalah 19, dengan persentase $67,8 \%$ termasuk dalam kategori kurang dengan nilai rata-rata 79,7. Rata-rata nilai hasil keterampilan siklus I yaitu 79,5 dengan rata-rata persentase ketuntasan belajar klasikal siswa pada siklus I sebesar 64,4 $\%$ dengan kategori kurang. Pada siklus II nilai hasil keterampilan/hasil belajar siswa juga mengalami peningkatan. Ini dapat dilihat pada pertemuan 1 siswa yang tuntas adalah 24 dengan persentase Ketuntasan Belajar Klasikal (KBK) sebesar 85,7\% dengan kategori baik. Pada pertemuan 2 siswa tuntas semua dengan persentase KBK sebesar 100\% dengan kategori sangat baik. Selain itu ditunjukkan dengan rata-rata nilai hasil keterampilan siswa pada siklus II meningkat dan memenuhi KKM yaitu 85,7 dengan rata-rata persentase ketuntasan belajar klasikal sebesar 92,8. 


\section{PEMBAHASAN}

Berdasarkan hasil penelitian menunjukkan bahwa penerapan model pembelajaran CIRC pada pembelajaran menulis puisi dikelas V SDN Sidodadi 02 Kabupaten Blitar dilaksanakan melalui dua siklus, yaitu siklus I dan siklus II. Dari hasil observasi aktivitas guru dan aktivitas siswa mengalami peningkatan. Penerapan model pembelajaran CIRC pada pembelajaran menulis puisi di kelas $\mathrm{V}$ SDN Sidodadi 02 dilaksanakan sesuai dengan fase-fase model pembelajaran CIRC menurut Shoimin (2016: 53) yaitu: (1) fase pertama orientasi, (2) fase kedua organisasi, (3) fase ketiga pengenalan konsep, (4) fase keempat publikasi, dan (5) fase penguatan dan refleksi.

Pelaksanaan pembelajaran menulis puisi dengan model pembelajaran CIRC pada siklus I belum terlaksana dengan optimal karena masih ada deskriptor dari fase model pembelajaran yang belum dilaksanakan oleh peneliti sebagai guru. Pada pertemuan 1 guru belum melaksanakan 3 deskriptor fase model pembelajaran CIRC yaitu: (1) guru belum menginformasikan aspek penilaian dalam menulis puisi, (2) guru belum memberi penguatan materi kepada siswa, dan (3) guru belum memberi kesempatan pada siswa untuk menanyakan materi yang belum dipahami. Hal ini karenakan guru kurang perhatian kepada siswa kelas $\mathrm{V}$ sehingga sebagian besar siswa masih bingung dengan apa yang dikerjakan karena tidak mengetahui aspek apa saja yang dinilai dalam menulis puisi, kurang detail dalam menjelaskan materi unsur-unsur fisik pembangun puisi dan guru langsung menarik kesimpulan sendiri tanpa melibatkan siswa. Sehingga siswa menjadi pasif. Selain itu berdasarkan catatan lapangan yaitu volume suara guru kurang keras ketika menjelaskan materi dan guru belum melibatkan siswa dalam. Sehingga untuk mengaktifkan kegiatan siswa, guru hendaknya memberikan perhatian pada siswa. Hal ini sesuai dengan Gagne dan Barliner (dalam Dimyati dan Mujiono, 2013: 42) bahwa perhatian memiliki peranan penting dalam kegiatan belajar karena tanpa adanya perhatian tidak mungkin terjadi umpan balik dalam pembelajaran, baik dari guru dengan siswa, maupun siswa dengan guru.

Pelaksanan siklus I pertemuan 2 berdasarkan aktivitas guru menunjukkan bahwa guru belum melakukan 1 deskriptor fase model pembelajaran CIRC yaitu guru belum memberi masukan kepada perwakilan kelompok yang membacakan puisi. Hal tersebut dikarenakan guru lupa dan belum terbiasa memberi masukan kepada siswa yang sifatnya dapat membangkitkan semangat belajar siswa dalam menulis maupun membacakan puisinya. Selain itu berdasarkan temuan lapangan yaitu: volume guru ketika menerangkan materi sudah keras, sehingga siswa lebih memperhatikan penjelasan guru, guru belum memberikan memberikan penguatan/motivasi pada siswa yang membacakan puisi. Seharusnya guru memberi masukan yang positif terhadap siswa melalui penguatan. Dengan memberi penguatan verbal seperti "Puisinya sudah bagus", sehingga siswa menjadi semangat dalam menulis puisi. Hal ini sejalan Sumanti dan Permana (dalam Aunurrahman 2009: 129) tujuan dari pemberi penguatan yaitu merangsang siswa untuk lebih berpikir dan meningkatkan motivasi belajar siswa.

Selain itu pemberian motivasi merupakan faktor yang penting untuk menumbuhkan rasa percaya diri untuk membacakan puisi. Hal ini sesuai dengan pendapat Djamarah dan Zain (2010: 148) kegiatan yang dilakukan guru untuk memberikan motivasi yaitu memberikan dorongan pada siswa untuk belajar lebih kiat, memberi penghargaan (reward) atas prestasi yang diraih supaya siswa selalu bersungguhsungguh dalam belajar. Sehingga nilai aktivitas guru pada pertemuan pertama sebesar $85 \%$ kategori baik dan pertemuan kedua sebesar 95\% dengan kategori sangat baik. Rata-rata persentase aktivitas guru pada siklus I sebesar 90\% dengan kategori B (Sangat Baik). Hal ini berdampak juga dengan aktivitas siswa karena kurang maksimal dalam menerapkan model pembelajaran CIRC. 
Pelaksanaan siklus I pertemuan 1 aktivitas siswa yaitu (1) siswa masih kurang percaya diri untuk menyampaikan tanggapan terhadap siswa yang membaca puisi. (2) Dalam menulis puisi siswa memerlukan waktu yang lebih banyak dari waktu yang ditentukan. Selain itu berdasarkan catatan lapangan siklus I pada pertemuan 1 yaitu: siswa ramai sendiri dan kurang memperhatikan penjelasan dari guru. (2) Siswa hanya mau membacakan puisi ketika ditunjuk guru. Hal ini dikarenakan guru belum bisa mengelola kelas. Seharusnya guru dapat mengelola kelas dengan baik karena pengelolan kelas merupakan faktor penentu keberhasilan pembelajaran. Hal ini sejalan dengan pendapat dari Djamarah dan Zain (2010: 194) pengelolaan kelas merupakan kompetensi guru yang sangat penting dikuasai oleh guru dalam kerangka keberhasilan proses belajar mengajar. Sehingga dalam pembelajaran seorang guru harus bisa mengelola kelas dengan baik supaya menciptakan pembelajaran yang aktif dan kreatif.

Pelaksanaan siklus I pertemuan 2 aktivitas siswa mulai tidak malu untuk membacakan hasil puisi. Siswa mulai aktif dalam kegiatan pembelajaran yaitu siswa mau menanggapi temannya yang membacakan puisi. Hal tersebut didukung catatan lapangan yaitu siswa mulai kondusif dalam kegiatan kelompok, siswa mulai percaya diri saat mengkomentari temannya yang membacakan puisi. Selain itu dikarenakan siswa terbiasa dengan model yang terapkan. Ini diperkuat dengan pendapat Shoimin (2016: 54) kelebihan yaitu CIRC sangat tepat untuk meningkatkan keterampilan siswa dalam menyelesaikan masalah yaitu dengan memberi tanggapan terhadap kelompok penyaji puisi. Sehingga aktivitas siswa pada siklus I pertemuan 1 persentase aktivitas siswa sebesar $67,9 \%$ dengan kategori kurang (D). Pertemuan kedua persentase aktivitas siswa sebesar 78,5\% dengan kategori cukup (C). Antara pertemuan pertama dan kedua mengalami peningkatan sebesar $10,7 \%$ dengan rata-rata persentase aktivitas siswa pertemuan 1 dan 2 yaitu 73,1 dengan kategori cukup (C).

Penerapan model pembelajaran CIRC pada pembelajaran menulis puisi di kelas V SDN Sidodadi 02 Kabupaten Blitar pada siklus II semua fase-fase model dilaksanakan dengan sangat baik. Hal ini di dukung dengan hasil observasi aktivitas guru yang mencapai $100 \%$ dengan kategori sangat baik. Pada pertemuan 1 dan untuk pertemuan 2 mencapai $100 \%$ dengan kategori sangat baik. Sehingga rata-rata persentase aktivitas guru pada siklus II sebesar $100 \%$ dengan kategori sangat baik. Selain itu berdasarkan hasil catatan lapangan pada siklus II pertemuan kesatu dan kedua yaitu: (1) guru sudah bisa mengelola kelas dengan kondusif, (2) guru sudah memberikan masukan kepada siswa, dan (3) guru sudah meningkatkan volume suara sehingga siswa lebih antusias dalam memperhatikan penjelasan guru. Hal ini sejalan dengan pendapat Djamarah dan Zain (2006: 167) suara guru dapat bervariasi untuk menunjukkan hal-hal yang penting. Sehingga dalam kegiatan pembelajaran volume suara guru sangat menentukan penyampaian materi.

Aktivitas siswa pada siklus II mengalami peningkatan. Hal ini dikarena aktivitas guru meningkat maka aktivitas siswapun juga meningkat. Ini terlihat dari persentase aktivitas siswa pada siklus II pertemuan 1 sebesar $89,3 \%$ dengan kategori baik. Pada pertemuan 2 dengan persentase $100 \%$ termasuk dalam kategori sangat baik. Rata-rata persentase aktivitas siswa sebesar 94,6 \% dengan kategori sangat baik, sehingga persentase aktivitas siswa meningkat dari siklus I ke siklus II sebesar $73,1 \%$ menjadi $94,6 \%$ dengan kategori sangat baik. Pada siklus II siswa sudah terbiasa dengan model pembelajaran CIRC sehingga siswa aktif dalam menjawab pertanyaan dari guru. Selain itu diperkuat dengan catatan lapangan yaitu siswa berani menyampaikan tanggapan terhadap teman yang membacakan puisi dengan percaya diri. Siswa lebih bertanggung jawab atas tugasnya dan 
tidak membutuhkan waktu yang lama untuk menulis puisi dan siswa berlatih kerjasama dalam kelompok. Hal ini diperkuat dengan pendapat Shoimin (2013: 54) yaitu dominasi guru dalam pembelajaran berkurang, siswa termotivasi pada hasil secara teliti karena bekerja dalam kelompok, siswa dapat memahami makna soal dan saling mengecek pekerjaannya, membantu siswa siswa yang lemah dalam menulis puisi dan, meningkatkan hasil belajar (keterampilan menulis siswa).

Berdasarkan pelaksanaan pembelajaran menulis puisi dengan menerapkan model pembelajaran CIRC di kelas V SDN Sidodadi 02 Kabupaten Blitar, hasil temuan penelitian menunjukkan bahwa keterampilan menulis puisi mengalami peningkatan. Nilai rata-rata pada pratindakan yaitu 77,3 hanya 11 siswa yang tuntas dengan persentase ketutasan belajar klasikal 39\% termasuk dalam kategori kurang. Pada siklus I pertemuan 1 hanya 17 siswa yang tuntas dan persentase ketuntasan belajar klasikal sebesar $61 \%$ termasuk kategori kurang dengan nilai rata-rata sebesar 79,3. Pada pertemuan 2 hanya 19 siswa yang tuntas dan rata-rata persentase ketuntasan klasikal sebesar $67,8 \%$ termasuk dalam kategori kurang dengan nilai rata-rata 79,7 . Ratarata persentase siklus I yaitu $64, \%$ termasuk dalam kategori kurang dengan nilai rata-rata 79,5. Pada siklus II pertemuan 1 ada 24 siswa yang tuntas dan persentase ketuntasan belajar klasikal sebesar $89,7 \%$ termasuk dalam kategori baik dengan nilai rata-rata 84,1. Pada pertemuan 2 ada 28 siswa yang tuntas dan persentase ketuntasan belajar klasikal meningkat menjadi $100 \%$ termasuk dalam kategori sangat baik dengan nilai rata-rata yaitu 87,4 . Rata-rata persentase ketuntasan belajar klasikal siklus II yaitu 92,8\% termasuk kategori sangat baik dengan nilai rata-rata 85,7 dan siswa yang tuntas adalah 26 .

Ketuntasan belajar secara klasikal minimal yang harus dicapai siswa menurut Sudjana (2009: 08) sebesar 80\%. Pelaksanaan pembelajaran dari siklus I ke siklus II mengalami peningkatan yang semakin baik.
Hasil keterampilan menulis siswa semakin meningkat karena guru selalu memberikan bimbingan kepada siswa yang mengalami kesulitan, guru mampu mengelola kelas dengan baik dan guru dapat membangkitkan semangat siswa untuk terus berlatih menulis puisi sehingga siswa menjadi lebih percaya diri, kreatif dan waktu yang digunakan menulis lebih cepat. Hal ini diperkuat dengan pendapat Saifulloh (dalam Huda, 2013: 221) model pembelajaran CIRC memiliki kelebihan yaitu: (1) menumbuh kembangkan keterampilan berpikir siswa, (2) menumbuhkan motivasi belajar yang optimal dan lebih bermakna, serta (3) menumbuh kembangkan rasa kerjasama tim serta memperluas wawasan siswa.

Berdasarkan hasil penelitian menunjukkan bahwa pembelajaran menulis puisi melalui model pembelajaran CIRC dapat meningkatkan keterampilan menulis puisi di kelas V SDN Sidodadi 02 Kabupaten Blitar. Hal ini dapat dilihat dari peningkatan hasil belajar keterampilan menulis puisi siswa. Selain itu diperkuat dengan penelitian terdahulu yang dilakukan Jumadi (2016) menunjukkan bahwa adanya peningkatan aktivitas dan nilai hasil siswa Kelas VIIB pada materi aktivitas menulis puisi bebas di SMPN 1 Bojong Kabupaten Pekalongan. Rata-rata nilai siswa mengalami peningkatan pada setiap siklus.

\section{PENUTUP}

Pembelajaran menulis puisi melalui model pembelajaran CIRC dapat meningkatkan keterampilan menulis puisi di kelas V SDN Sidodadi 02 Kabupaten Blitar. Hal ini dapat dilihat dari peningkatan hasil belajar keterampilan menulis puisi siswa. Saran untuk guru hendaknya dapat mengkondisikan kelas dengan mendesain pembelajaran yang lebih menarik untuk siswa, sehingga siswa termotivasi untuk berani menanggapi dan mempublikasikan puisi yang telah ditulis. Serta hendaknya guru sering membentuk kelompok- kelompok kecil dalam pembelajaran, untuk melatih kerjasama antar siswa dengan menerapkan model pembelajaran CIRC. Siswa 
hendaknya selalu terlibat langsung dalam pembelajaran de-ngan menjawab pertanyaan semua pertanyaan guru dengan percaya diri. Siswa hendaknya terus berlatih secara kontinu dalam menulis puisi untuk menguasai keterampilan menulis. Sekolah hendaknya memfasilitasi dan mendukung guru dalam mengembangkan pem-belajaran yang lebih inovatif.

\section{DAFTAR RUJUKAN}

Arikunto, Suharsimi dkk. 2010. Penelitian Tindakan Kelas. Jakarta: PT Bumi Aksara Aunurrahman. 2009. Belajar dan Pembelajaran. Bandung: Alfabeta

BNSP. 2006. Standar Isi Kurikulum Tingkat

Satuan Pendidikan. Jakarta: Badan Standar Nasional Pendidikan.

Dimyati dan Mudjiono. 2013. Belajar dan Pembelajaran. Jakarta: Rineka Cipta.

Djamarah, Syaiful Bahri dan Aswan Zain. 2010. Strategi Belajar Mengajar. Jakarta: Rineka Cipta.

Hitipieuw, Imanuel. 2009. Belajar dan Pembelajaran. Malang: Fakultas Ilmu Pendidikan Universitas Negeri Malang.

Huda, Miftahul. 2013. Model-Model Pengajaran dan Pembelajaran. Yogyakarta: Pustaka Pelajar.

Iskandarwassid \& Sunendar, Dadang. 2015. Strategi Pembelajaran Bahasa. Bandung: PT Remaja Rosdakarya.

Jumadi.2016. Peningkatan Kompetensi Menulis Puisi Bebas Menggunakan Model Pembelajaran Cooperative Integrated Reading and Composition (CIRC) Kelas VIIB SMPN 1 Bojong Kabupaten Pekalongan. Jurnal Praktik Penelitian Tindakan Kelas Pendidikan Dasar \& Menengah, (Online), 6 (1): 22-
26, (https://irpp.com/index.php/dinamika/ article/download/408/398), diakses pada 01 Januari 2017

Mudiono, Alif. 2010. Pengembangan Bahan Pembelajaran Bahasa Indonesia Sekolah Dasar. Malang: FIP UM.

Saddhono, Kundharu \& Slamet, St. Y. 2014. Pembelajaran Keterampilan Berbahasa Indonesia; Teori dan Aplikasi Edisi 2. Yogyakarta: Graha Ilmu.

Shoimin, Aris. 2016. 68 Model Pembelajaran Inovatif dalam Kurikulum 2013 (Rose, Ed.). Yogyakarta: Ar-Ruz Media.

Slavin, Robert E. 2010. Cooperative Learning. Bandung: Penerbit Nusa Media.

Sudjana, Nana. 2009. Penelitian Hasil Proses Belajar Mengajar. Bandung: Rosdakarya.

Sugiyono. 2013.Metode Penelitian Pendidikan (Pendekatan Kuantitatif, Kualitatif dan $R \& D)$. Bandung: Alfabeta.

Supriyadi. 2006. Pembelajaran Sastra yang Apresiatif dan Integratif di Sekolah Dasar. Jakarta: Depdiknas Dirjen Dikti Direktorat Ketenagaan.

Wardoyo, Sigit Mangun. 2013. Teknik Menulis Puisi. Yogyakarta: Graha Ilmu. 